\title{
Assessment of Natural Radioactivity Level and Annual Effective Dose of Amber Rice Samples Cultivated in the South of Iraq
}

\author{
Abdulridha S. Younis ${ }^{1, *}$ and Nada F. Tawfiq ${ }^{2}$ \\ ${ }^{1}$ Al-Kitab University, Kirkuk, Iraq \\ ${ }^{2}$ Al-Nahrain University, Baghdad, Iraq
}

\begin{abstract}
In this work, the activity concentrations of naturally occurring radioactive material including ${ }^{238} \mathrm{U},{ }^{232} \mathrm{Th}$, and ${ }^{40} \mathrm{~K}$ were measured of some amber rice samples cultivated in southern Baghdad and $\mathrm{Al}$ Najaf governorate and used in Baghdad governorate, Iraq in 2018, using gamma-ray spectrometer with $\mathrm{NaI}$ (Tl) detector. The results show that the activity concentrations for ${ }^{238} \mathrm{U}$ ranged from (2.68 to 10.81$) \mathrm{Bq} / \mathrm{kg}$ with average $5.94 \mathrm{~Bq} / \mathrm{kg},{ }^{232} \mathrm{Th}$ ranged from (B.D.L to 3.37) Bq/kg with average $2.65 \mathrm{~Bq} / \mathrm{kg}$, and for ${ }^{40} \mathrm{~K}$ ranged from (4.48 to 35.7$) \mathrm{Bq} / \mathrm{kg}$ with average $16.84 \mathrm{~Bq} / \mathrm{kg}$. The annual effective dose from rice consumption by adults for ${ }^{238} \mathrm{U},{ }^{232} \mathrm{Th}$, and ${ }^{40} \mathrm{~K}$ ranged from $(0.41$ to 1.6$) \times 10^{-5} \mathrm{~Sv} / \mathrm{y}$ with average $0.9 \times 10^{-5}$ $\mathrm{Sv} / \mathrm{y}$, (B.D.L to 0.42$) \times 10^{-5} \mathrm{~Sv} / \mathrm{y}$ with average $0.2 \times 10^{-5} \mathrm{~Sv} / \mathrm{y}$, and $(0.17$ to 1.2$) \times 10^{-5} \mathrm{~Sv} / \mathrm{y}$ with average $0.45 \times 10^{-5} \mathrm{~Sv} / \mathrm{y}$ respectively. All values of the average specific activities are less than the global average values of ICRP, and the annual effective dose from rice consumption by adults was lower than the permissible limit of $(1 \mathrm{~m} \mathrm{~Sv} / \mathrm{y})$ recommended by the International Commission on Radiological Protection.
\end{abstract}

\section{Introduction}

Radionuclides are found throughout nature and exist in the soil, water and food. These radionuclides have halflives that are approximately the earth's age or older (i.e. about 4 to 5 billion years) [1]. Natural radioactive decay series such as ${ }^{238} \mathrm{U}$ and ${ }^{232} \mathrm{Th}$ as well as singly occurring radionuclides such as ${ }^{40} \mathrm{~K}$ exist in the earth and atmosphere in varied levels. The radioactivity present in air or in the agricultural land and in soil may transfer to the crops grown on it. It happens, however, that an amount of some radioactive elements find their way into human bodies [2]. When plants are grown in the contaminated soil, the radioactivity is transferred from the soil to the roots. In the end, the radioactivity is shifted to the human diet [3]. These radionuclides will get transferred into plants together with the nutrients throughout mineral uptake and accumulation in varied components and even reach edible portions [4].

It is well known that traces of radionuclides are found in air, soil, water and human bodies, we inhale and ingest radionuclides every day of our lives and radioactive materials have been ubiquitous on earth since its creation $[1,5]$.

Natural Uranium is considered as one of the most important primordial radionuclides in the earth's crust. It is found in varying soil but small amounts, for example, rocks, soils, water, air, plants, animals and in all human beings. On average, about $(90 \mu \mathrm{g})$ of uranium exist in the human body which comes from the normal intakes of food, water, and air. Approximately (66\%) was found in the skeleton, $(16 \%)$ in liver, $(8 \%)$ in kidneys and $(10 \%)$ in other tissues of the body $[6,7]$.

The physiological behaviour of uranium compounds depends mainly on their solubility, when ingested, uranium might be concentrated within the bones; it increases the probability of bone cancer, or in the red bone marrow (leukemia). [8,9]

The kidney is considered the target for uranium chemical toxicity, which causes irreversible damage to the kidney leading to growth of tumours. A large quantity of uranium in the kidney can impair renal function. [10, 11, 12,13,14].

The Aim of the study is to determine the specific activities of natural Oradionuclides $\left({ }^{238} \mathrm{U},{ }^{232} \mathrm{Th}\right.$, and $\left.{ }^{40} \mathrm{~K}\right)$ in amber Iraqi rice samples cultivated in the middle and the south of the country using Gamma spectroscopy technique with $\mathrm{NaI}(\mathrm{Tl})$ scintillation detector.

And to evaluate the annual effective dose from the rice consumption by individual consumers due to intake of the concerned the above radionuclides.

\section{Materials and Methods}

Three rice samples (1 $\mathrm{kg}$ weight of each sample) were collected from fives farming fields (two from south Baghdad and three samples from Al-Najaf governorate farming fields area are shown in table (1), these samples are kept in Marinally beakers and stored for 30 days before gamma ray analysis is done to allow ${ }^{226} \mathrm{Ra}$ and its short-lived progenies to reach secular equilibrium between uranium and thorium with respective progenies. 
Table 1. Rice Samples collected locations

\begin{tabular}{|c|c|}
\hline Sample & Location \\
\hline S1 & southern Baghdad \\
\hline S2 & southern Baghdad \\
\hline S3 & AL Najaf governorate \\
\hline S4 & AL Najaf governorate \\
\hline S5 & AL Najaf governorate \\
\hline
\end{tabular}

Measuring the Specific activity of natural Radionuclides is done by using $\mathrm{NaI}(\mathrm{Tl})$ scintillation detector (The sodium iodide $\mathrm{NaI}(\mathrm{Tl})$ (CANBRA-USA) to PC-MCA (4096 channel) operating voltage $(750 \mathrm{~V})$, $(3 \times 3$ inch), and $60 \%$ efficiency and the delectability of the energy detector values (1332) MeV. The detector is surrounded by a lead shield to reduce the background radiation.

The energy calibration of gamma spectrometer were carried out using standard sources in one litter marinelli beaker mixed radio nuclides with energies $(59.53,88.34$, 661.7, and 1178 ) $\mathrm{keV}$ for ${ }^{214} \mathrm{Am},{ }^{109} \mathrm{Cd},{ }^{137} \mathrm{Cs}$, and ${ }^{60} \mathrm{Co}$ respectively (figure :1)

The software (GIENE 2000) program is used to quantify the measurements and to analyze the results.

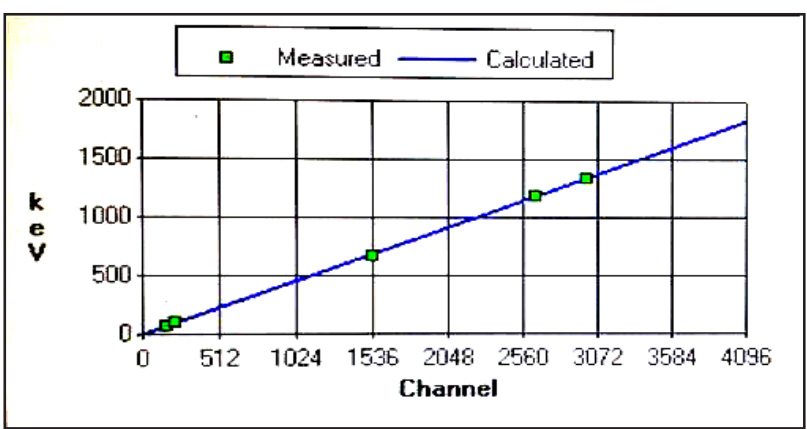

Fig. 1. Energy Calibration Curve.

The efficiency $e_{f}$ at energy (E $\left.\gamma\right)$ was calculated according to equation: 1 below.

$$
e_{f}=\frac{\mathrm{N}}{\mathrm{A} * \mathrm{I} \gamma * \mathrm{~T}} * 100 \%
$$

Where:

$e_{f}$ : The efficiency at energy $(\mathrm{E} \gamma)$.

$\mathrm{N}$ : the net area under the peak at specific peak at energy (E $\gamma)$.

A: is the activity of the standard source in $(\mathrm{Bq})$.

$\mathrm{I} \gamma$ : is the abundance at energy (E $\gamma)$.

T: measurement time which equal to (1800s).

To find the efficiencies of other energies of any radioactive isotopes by the efficiency calibration curve as shown in Fig. 2.

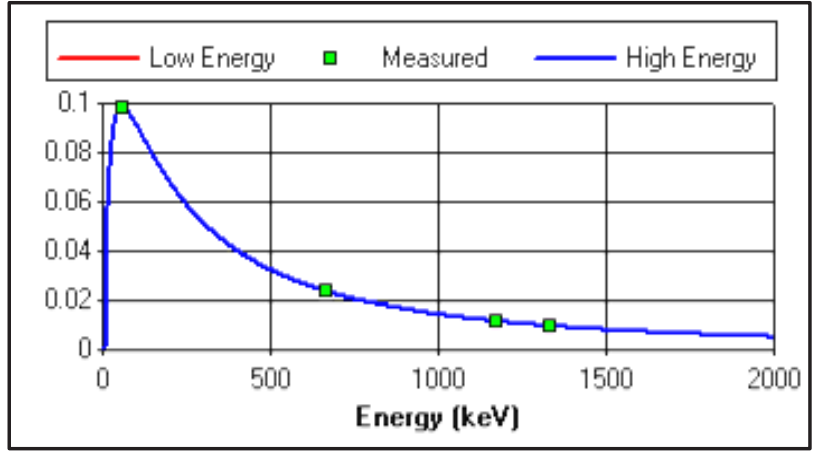

Fig 2. Efficiency Calibration curve

The specific activity of the radionuclides, in $(\mathrm{Bq} / \mathrm{kg})$ units, in rice samples were obtained by using equation: 2 $[15,16]$ :

$$
A=\frac{N-B . G}{T \times \mathrm{I} \gamma \times E \mathrm{ff} \times M}
$$

Where:

A: is the specific activity concentration of radionuclide in $(\mathrm{Bq} / \mathrm{kg}), \mathrm{N}$ : is the area under the peak .

B.G: is the peak of background with shielding.

$\mathrm{M}$ : is the mass of the sample $(\mathrm{kg})$.

$\mathrm{I} \gamma:$ is the intensity at energy $(\mathrm{E} \gamma)$.

Eff: is the efficiency at energy (E $\gamma)$.

$\mathrm{T}$ : is the time of measurement which is equal to (1800s)

\section{The Annual Effective Dose}

The annual effective dose was calculated by the following formula [17]:

$$
E=C * R * F_{C}
$$

Where: $\mathrm{E}$ is the annual effective dose (Sv/y),

$\mathrm{C}=$ Concentration $(\mathrm{Bq} / \mathrm{kg})$,

$\mathrm{R}=$ Consumption rates of food ( $\mathrm{kg} /$ year) which is equal to $55 \mathrm{~kg} / \mathrm{y}$.

$\mathrm{Fc}=$ Dose conversion factor for ingestion is equal to $\left(4.5 \times 10^{-5} \mathrm{mSv} / \mathrm{Bq}\right)$ for uranium, IAEA $1996[18,19]$.

\section{Results and Discussions}

The specific activity of natural radionuclides ${ }^{238} \mathrm{U},{ }^{232} \mathrm{Th}$ and ${ }^{40} \mathrm{k}$ in rice samples were given in Table 2 .

The range of specific activity concentration for ${ }^{238} \mathrm{U}$ varied from (2.68 to 10.81$) \mathrm{Bq} / \mathrm{kg}$ with average 5.94 $\mathrm{Bq} / \mathrm{kg}$, the highest specific activity levels was found in sample S1 (from southern Baghdad), which can be referred to as the cumulative of this radionuclide in the rice and the minimum activity level found in sample S3 from (Al-Najaf governorate) as shown in table 2 and Fig. 3. The range of specific activity for ${ }^{232} \mathrm{Th}$ varied from (B.D.L to 3.37) $\mathrm{Bq} / \mathrm{kg}$ with average $2.65 \mathrm{~Bq} / \mathrm{kg}$, the highest specific activity levels was found in sample S1 (southern Baghdad), and the minimum activity level found in sample S2 and S4 (southern Baghdad and AlNajaf governorate), as shown in Fig. 4. 
The range of specific activity for ${ }^{40} \mathrm{~K}$ varied from (4.88 to 35.7 ) $\mathrm{Bq} / \mathrm{kg}$ with average $16.84 \mathrm{~Bq} / \mathrm{kg}$, the highest specific activity levels were found in sample S5 (Al-Najaf governorate) and the minimum activity level found in sample S3 (Al-Najaf governorate) as shown in Fig. 5.

The average specific activities of ${ }^{238} \mathrm{U},{ }^{232} \mathrm{Th}$ and ${ }^{40} \mathrm{~K}$ were shown in Fig 6, all values of the average specific activities are less than the global average values $[8,22]$.

As seen in Table 3, the annual effective dose from rice consumption by adults indicates that the annual effective dose in all samples were lower than the maximum permissible limit of $(1 \mathrm{mSv} / \mathrm{y})$ recommended by the International Commission on Radiological Protection (ICRP). [17, 18].

Table 2. The average Specific activities of natural radionuclides in rice samples

\begin{tabular}{|c|c|c|c|}
\hline \multirow{2}{*}{ Sample } & \multicolumn{3}{|c|}{$\begin{array}{c}\text { Specific Activity Concentration } \\
(\mathrm{Bq} / \mathrm{kg})\end{array}$} \\
\cline { 2 - 4 } & ${ }^{238} \mathrm{U}$ & ${ }^{232} \mathrm{Th}$ & ${ }^{40} \mathrm{~K}$ \\
\hline $\mathrm{S} 1$ & 10.81 & 3.37 & 12.2 \\
\hline $\mathrm{S} 2$ & 4.42 & B.D.L & 13.9 \\
\hline $\mathrm{S} 3$ & 2.68 & 3.18 & 4.88 \\
\hline S4 & 6.23 & B.D.L & 17.5 \\
\hline S5 & 5.55 & 1.41 & 35.7 \\
\hline Max. & 10.81 & 3.37 & 35.7 \\
\hline Min. & 2.68 & B.D.L & 4.48 \\
\hline Average & 5.94 & 2.65 & 16.84 \\
\hline
\end{tabular}

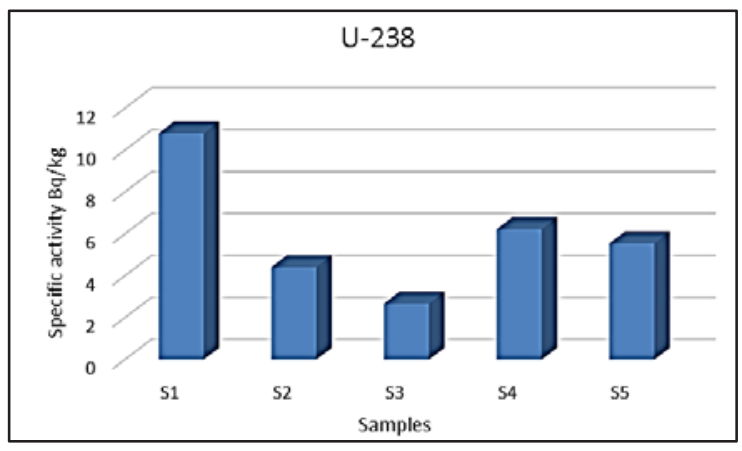

Fig. 3. The specific activity of $238 \mathrm{U}$ in rice samples

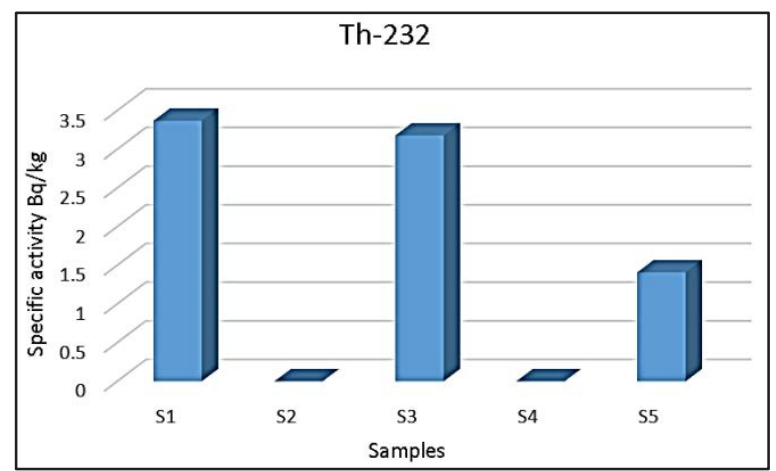

Fig. 4. The specific activity of ${ }^{232} \mathrm{Th}$ in rice samples

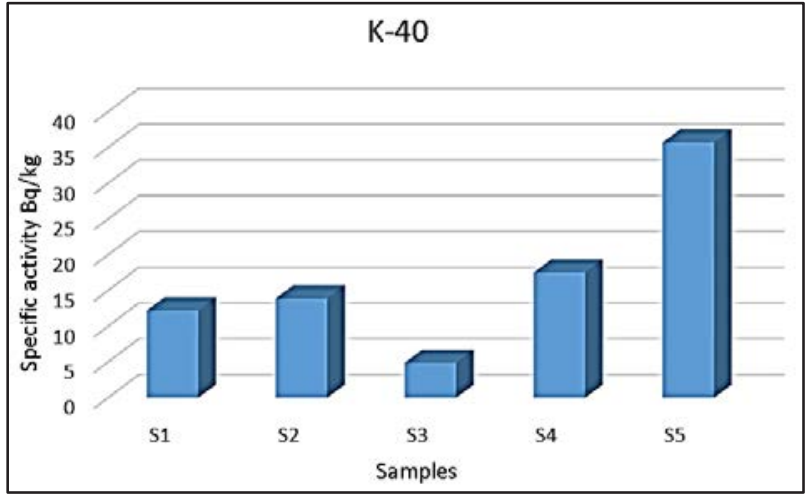

Fig. 5. The specific activity of ${ }^{40} \mathrm{~K}$ in rice sample

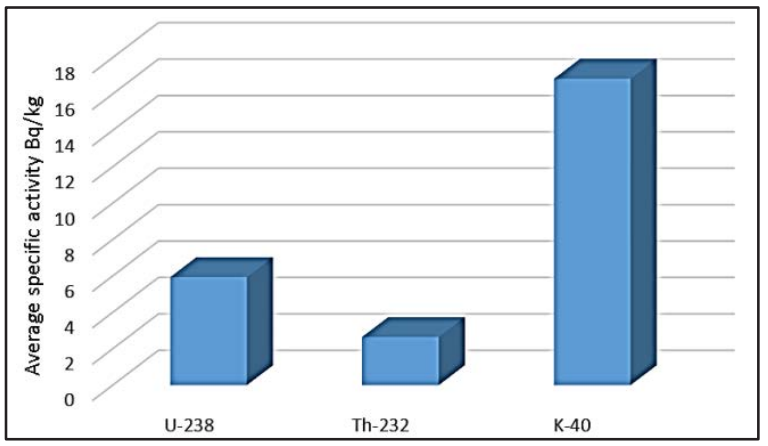

Fig. 6. The average specific activities of ${ }^{238} \mathrm{U},{ }^{232} \mathrm{Th}$ and ${ }^{40} \mathrm{~K}$ in rice samples

Table 3. The annual Effective Dose in rice samples

\begin{tabular}{|c|c|c|c|}
\hline \multirow{2}{*}{ Sample } & \multicolumn{3}{|c|}{ Annual Effective Dose $\times 10^{-5}(\mathrm{~Sv} / \mathrm{y})$} \\
\cline { 2 - 4 } & ${ }^{238} \mathrm{U}$ & ${ }^{232} \mathrm{Th}$ & ${ }^{40} \mathrm{~K}$ \\
\hline S1 & 1.6 & 0.42 & 0.42 \\
\hline S2 & 0.68 & B.D.L & 0.47 \\
\hline S3 & 0.41 & 0.40 & 0.17 \\
\hline S4 & 0.96 & B.D.L & 0.60 \\
\hline S5 & 0.85 & 0.18 & 1.2 \\
\hline Max. & 1.6 & 0.42 & 1.2 \\
\hline Min. & 0.41 & B.D.L & 0.17 \\
\hline Average & 0.9 & 0.2 & 0.45 \\
\hline
\end{tabular}

\section{Conclusions}

The Specific activities of Natural radionuclides ${ }^{238} \mathrm{U}$, ${ }^{232} \mathrm{Th}$ and ${ }^{40} \mathrm{~K}$ ) in all samples are lower than the worldwide median values reported by UNSCEAR.[8]

Also it was found that the annual effective doses due to the ingestion of all three natural radionuclides by adults are below the recommended limit by the International Commission on Radiological Protection for radiological safety ICRP.[11, 12,13,14]

\section{References}


1. Raymond Murray L. Understanding Radioactive Waste. Battelle Press. Columbus. Ohio: Fourth Edition 1994.

2. U.S. Environmental Protection Agency Radiation Protection Program-Uranium, 2015.

3. The Governorate of the Hong Kong Special Administrative. 'Radiation and food Safety 2013.

4. Laith A. Najam, Nada F. Tawfiq, Fouzey H. Kitah, (2015), Estimation of Natural Radioactivity of Some Medicinal or Herbal Plants Used in Iraq, Detection, 3, 1-7.

5. Cember H., Thomas E. Johnson, Introduction to Health Physics, Fifth Edition, McGraw Hill Education, USA, 2017.

6. Peter van Calsteren, Louise Thomas, Uranium-series dating applications in natural environmental science, Earth-Science Reviews, Vol. 75, Issues 1-4, 155$175,2006$.

7. Harigel G.: "Depleted Uranium Weapons - A threat to Human Health?" 2002.

8. UNSCEAR, United Nations Scientific Committee on the Effects of Atomic Radiation, Report to the General Assembly: Sources and Effects of Ionizing Radiation, New York, Vol.1, 2000.

9. Asaf, D., "Medical Consequences of Contamination with Depleted

10. Uranium", In "Metal of Dishonor", International Action Center, New York, 1999.

11. Deitzy, "Uranium Battle Fields", Progressive Alliance for Community, New Mexico, 1993.

12. ICRP, Recommendations of the International Commission on Radiological Protection. ICRP Publication 60. Ann. ICRP 21 (1-3), 1991.
13. Linnea E. Wahl, Environmental Radiation, Health Physics Society Specialists in Radiation Safety January, 2010.

14. ICRP, "Radiation Protection", Report of Committee IV on Evaluation of Radiation Dose to Body Tissues from Internal Contamination due to occupational Exposure, Pergamon Press, Oxford, 1968.

15. Ridha, A. A., "Determination of radionuclides' concentrations in construction materials used in Iraq " Ph.D. Thesis, College of Science, Al-Mostansrya University, 2013.

16. Hussain R.O. and Abbas E.K. " Measurement of Natural Occurring Radio nuclides (NORMs) in Soil using Gamma- ray Spectrometry " Journal of ALKufa ,2, No.2,15-22, 2010.

17. Karim M.S, Chiad,S. S., Habubi, N.F, Mansour,H.L., and Mishjil, K.A." Study of specific activities of some biological samples for selected Iraqi governorates" Fondazione Giorgio Ronchi, ANNO, LXVIII, No.1, 2013.

18. ICRP, 2009. Application of the Commission's recommendations for the protection of people in emergency exposure situations. ICRP Publication 109. Ann. ICRP 39 (1).

19. IAEA, 1996, International basic safety standards for protection against ionizing radiation and safety of radiation sources, Safety Series 115, Vienna. 